\title{
AN EVALUATION OF THE NUTRITIONAL VALUE OF RICOTTA SOLD ON THE POLISH MARKET
}

\section{OCENA WARTOŚCI ODŻYWCZEJ RICOTT DOSTĘPNYCH NA POLSKIM RYNKU}

\author{
Department of Dairy Science and Quality Management, University of Warmia and Mazury \\ in Olsztyn, Poland \\ 1Department of Commodity Science and Food Analysis, University of Warmia and Mazury \\ in Olsztyn, Poland \\ 2Department of Process Engineering and Equipment, University of Warmia and Mazury \\ in Olsztyn, Poland
}

\begin{abstract}
Streszczenie. Przeprowadzono ocenę wartości odżywczej ricott dostępnych na polskim rynku. Materiał badawczy stanowiły ricotty niedojrzewające pochodzące od czterech producentów, zakupione w handlu detalicznym na terenie Olsztyna. W badanych ricottach oznaczono zawartość suchej masy - metodą suszenia, białka ogółem - metodą makro, tłuszczu - metodą butyrometryczną, laktozy - metodą Bertranda, popiołu - metodą spalania. W celu oznaczenia składników mineralnych próbki analizowanych ricott mineralizowano na mokro. $\mathrm{Ca}, \mathrm{Mg}, \mathrm{Zn}, \mathrm{Fe}$ i Cu oznaczano techniką płomieniowej spektrometrii absorpcji atomowej (płomień acetylen powietrze), K i Na - techniką emisyjną (płomień acetylen - powietrze), natomiast $\mathrm{P}$ - metodą kolorymetryczną. Obliczono wartość energetyczną badanych produktów. Ocenę wartości odżywczej ricott przeprowadzono, obliczając wskaźnik jakości żywieniowej (INQ) w odniesieniu do potrzeb odżywczych kobiet oraz mężczyzn w wieku 19-50 lat o umiarkowanej aktywności fizycznej. Badane ricotty wykazywały różnice w składzie chemicznym. Ich wartość energetyczna zależała głównie od zawartości tłuszczu. Wartości INQ wskazują, że badane ricotty stanowiły bogate źródło białka i tłuszczu. Ricotty od trzech producentów były dobrym źródłem Ca i P, a stosunek zawartości tych makroelementów był korzystny dla biodostępności Ca. Ricotty od dwóch producentów stanowiły dobre źródło Na. Ricotta od jednego producenta wykazywała optymalny stosunek zawartości $\mathrm{K}$ do $\mathrm{Na}$. Badane ricotty charakteryzowały się niedoborem zawartości cukrów, K, Mg, Zn, Fe oraz Cu w odniesieniu do potrzeb odżywczych kobiet i mężczyzn w wieku 19-50 lat o umiarkowanej aktywności fizycznej.
\end{abstract}

Key words: ricotta, chemical composition, energy value, nutritional value, Index of Nutritional Quality (INQ).

Słowa kluczowe: ricotta, skład chemiczny, wartość energetyczna, wartość odżywcza, wskaźnik jakości żywieniowej (INQ).

\section{INTRODUCTION}

Ricotta is a dairy product that is highly popular in Italy. Ricotta is often considered a cheese, although it actually does not fulfill the definition of cheese, as indicated by Mucchetti et al. (2002).

Corresponding author - Adres do korespondencji: Krzysztof Siemianowski, Department of Dairy Science and Quality Management, University of Warmia and Mazury in Olsztyn, Michała Oczapowskiego 7, 10-719 Olsztyn, Poland, e-mail: krzysztof.siemianowski@uwm.edu.pl 
Traditional ricotta is made of whey, including whey obtained during the production of cheese from cow's, buffalo's, ewe's and goat's milk, as well as a mixture of whey, milk and/or cream. Ricotta is produced by heating the whey and adjusting its $\mathrm{pH}$ to denature and aggregate protein. The precipitated coagulant is then separated, the product is cooled and packaged. Ricotta is sold mainly as a fresh (unripened) product, but salted and smoked variants are also available. Fresh ricotta is characterized by a slightly sweet flavor, milky and creamy aroma and granular structure (Mucchetti et al. 2002). Ricotta is used to prepare desserts, pastries, pasta dishes, crepe and dumpling fillings, and bread spreads (Pintado et al. 2001; Kolanowski 2005).

Nutrition plays a key role in human health and wellbeing. A balanced diet that meets the energy and nutritional demands of individuals and contributes to the prevention of diet-dependent diseases is crucial for health maintenance (Biernat and Wyka 2011). The nutritional value of foods can be reliably evaluated based on the Index of Nutritional Quality (INQ) which is the ratio between the percentage of the reference intake of energy and each nutrient and the percentage of the average requirement for energy and nutrients provided by food. The INQ values of different food products are very helpful in planning, evaluating and modifying individuals' daily diets (Gawęcki and Roszkowski 2010).

There is a general scarcity of published data regarding the nutritional value of ricotta. This study attempts to fill this knowledge gap by evaluating the nutritional value of ricotta available on the Polish market.

\section{MATERIAL AND METHODS}

The experiment was performed on fresh (unripened) ricotta supplied by four manufacturers, purchased in retail in the city of Olsztyn, Poland. In each group of products originating from the same manufacturer, chemical analyses were carried out on the same product batch. The evaluated products were marked with letters $(A, B, C, D)$ to maintain the manufacturers' anonymity. The country of origin and the composition of the analyzed ricotta are presented in Table 1.

Table 1. Country of origin and composition of the analyzed ricotta based on label data

Tabela 1. Kraj pochodzenia oraz skład surowcowy badanych ricott według informacji podanych na opakowaniach produktów

\begin{tabular}{|c|c|c|}
\hline Ricotta & $\begin{array}{l}\text { Country of origin } \\
\text { Kraj } \\
\text { pochodzenia }\end{array}$ & $\begin{array}{l}\text { Composition } \\
\text { Skład surowcowy }\end{array}$ \\
\hline $\begin{array}{l}\text { Manufacturer } \\
\text { Producent } \\
\text { A } \\
\text { Manufacturer } \\
\text { Producent } \\
\text { B }\end{array}$ & $\begin{array}{l}\text { Italy } \\
\text { Włochy } \\
\text { Italy } \\
\text { Włochy }\end{array}$ & $\begin{array}{l}\text { milk whey, sweet cream, acidity regulator: citric acid } \\
\text { serwatka z mleka, śmietanka, regulator kwasowości: kwas cytrynowy } \\
\text { whey (milk), milk, salt, acidity regulator: citric acid } \\
\text { serwatka z mleka, mleko, sól, regulator kwasowości: kwas cytrynowy }\end{array}$ \\
\hline $\begin{array}{l}\text { Manufacturer } \\
\text { Producent } \\
\text { C }\end{array}$ & $\begin{array}{c}\text { Italy } \\
\text { Włochy }\end{array}$ & $\begin{array}{l}\text { pasteurized whey (milk), sweet cream and/or whey cream (milk), salt, } \\
\text { acidity regulators: lactic acid, citric acid } \\
\text { pasteryzowana serwatka z mleka, śmietanka i/lub śmietanka serwatkowa } \\
\text { z mleka, sól, regulatory kwasowości: kwas mlekowy, kwas cytrynowy }\end{array}$ \\
\hline $\begin{array}{l}\text { Manufacturer } \\
\text { Producent } \\
\text { D }\end{array}$ & $\begin{array}{c}\text { Italy } \\
\text { Włochy }\end{array}$ & $\begin{array}{l}\text { whey from pasteurized cow's milk, sweet cream, salt, acidity regulator: } \\
\text { lactic acid } \\
\text { serwatka z pasteryzowanego mleka krowiego, śmietanka, sól, regulator } \\
\text { kwasowości: kwas mlekowy }\end{array}$ \\
\hline
\end{tabular}


Ricotta samples were analyzed to determine their dry matter content - by drying at a temperature of $102^{\circ} \mathrm{C}$ (PN-EN ISO $\left.5534: 2005\right)$, total protein content - by the block-digestion (macro) method (PN-EN ISO 8968-2 : 2004), fat content - by the butyrometric method (PN-A-86232 : 1973), lactose content - by the Bertrand method (PN-A-86232 : 1973), and total ash content - by incineration in a chamber oven at a temperature of $550^{\circ} \mathrm{C}$ (Krełowska-Kułas 1993). Ricotta samples were analyzed to determine their mineral content, including the content of macroelements - calcium $(\mathrm{Ca})$, phosphorus $(\mathrm{P})$, potassium $(\mathrm{K})$, sodium $(\mathrm{Na})$, magnesium $(\mathrm{Mg})$, and microelements - zinc $(\mathrm{Zn})$, iron (Fe), copper $(\mathrm{Cu})$. The samples were wet mineralized in a mixture of nitric acid and perchloric acid $(3: 1, \mathrm{v} / \mathrm{v})$ in an electric block digester (DK 20, VELP Scientifica, Italy) for 4-5 hours, where temperature was gradually increased from $120^{\circ} \mathrm{C}$ to $200^{\circ} \mathrm{C}$. Mineralized samples were transferred to $25 \mathrm{~cm}^{3}$ measuring flasks and supplemented with deionized water to the calibration mark. Reagent samples were prepared simultaneously. The content of $\mathrm{Ca}, \mathrm{Mg}, \mathrm{Zn}, \mathrm{Fe}$ and $\mathrm{Cu}$ in mineralized samples was determined by flame atomic absorption spectrometry (air-acetylene flame) in the iCE 3000 Series AAS spectrometer (Thermo Scientific, UK) equipped with a GLITE data processing station, deuterium background correction and cathode lamps. To eliminate the effect of $\mathrm{P}$ in $\mathrm{Ca}$ analyses, the evaluated samples and reference standards were combined with an aqueous solution of lanthanum chloride to obtain $0.5 \%$ concentration of $\mathrm{La}^{+3}$ (Whiteside and Miner 1984). The content of minerals in ricotta was determined at the following wavelengths: $422.7 \mathrm{~nm}(\mathrm{Ca}), 285.2 \mathrm{~nm}(\mathrm{Mg})$, $213.9 \mathrm{~nm}(\mathrm{Zn}), 248.3 \mathrm{~nm}(\mathrm{Fe})$ and $324.8 \mathrm{~nm}(\mathrm{Cu})$. The content of $\mathrm{K}$ and $\mathrm{Na}$ was analyzed by atomic emission spectrometry (air-acetylene flame) at a wavelength of $766.5 \mathrm{~nm}(\mathrm{~K})$ and $589.0 \mathrm{~nm}(\mathrm{Na}$ ). The content of $\mathrm{P}$ was analyzed colorimetrically (Markiewicz 2000), and absorbance was measured in a spectrophotometer (VIS 6000, KRÜSS - OPTRONIC, Germany) at $610 \mathrm{~nm}$.

The energy value of ricotta was calculated based on Atwater conversion factors where: $1 \mathrm{~g}$ of protein $=4.0 \mathrm{kcal}, 1 \mathrm{~g}$ of sugar $=4.0 \mathrm{kcal}, 1 \mathrm{~g}$ of fat $=9.0 \mathrm{kcal}$ (Jarosz et al. 2012b).

The nutritional value of ricotta was determined by calculating the INQ values of nutrients relative to the recommended dietary allowances - RDA (protein, fat, available sugars, $\mathrm{Ca}, \mathrm{P}$, $\mathrm{Mg}, \mathrm{Zn}, \mathrm{Fe}, \mathrm{Cu})$ or adequate intake $-\mathrm{Al}(\mathrm{K}, \mathrm{Na})$, separately for moderately physically active $(P A L=1.75)$ men and women aged $19-50$ years, according to the below equation (Gawęcki and Roszkowski 2010):

$$
I N Q=\frac{\text { nutrient content in } 100 \mathrm{~g} \text { of product } \times \text { energy requirements }}{\text { energy value in } 100 \mathrm{~g} \text { of product } \times \text { nutrient requirements }}
$$

The following daily energy and nutrient requirements were adopted for women with the average body mass of $60 \mathrm{~kg}$ : energy $-2350 \mathrm{kcal}$, protein $-54 \mathrm{~g}(0.9 \mathrm{~g}$ per $\mathrm{kg}$ of body mass), fat $-78.5 \mathrm{~g}$ ( $30 \%$ of dietary energy), available sugars $-130 \mathrm{~g}$, calcium $-1000 \mathrm{mg}$, phosphorus $700 \mathrm{mg}$, potassium - $4700 \mathrm{mg}$, sodium - $1500 \mathrm{mg}$, magnesium - $315 \mathrm{~g}$, zinc - $8000 \mu \mathrm{g}$, iron $18.000 \mu \mathrm{m}$, copper $-900 \mu \mathrm{g}$. The following daily energy and nutrient requirements were adopted for men with the average body mass of $70 \mathrm{~kg}$ : energy $-3000 \mathrm{kcal}$, protein $-63 \mathrm{~g}(0.9 \mathrm{~g}$ per $\mathrm{kg}$ of body mass), fat $-100 \mathrm{~g}$ ( $30 \%$ of dietary energy), available sugars $-130 \mathrm{~g}$, calcium $-1000 \mathrm{mg}$, phosphorus - $700 \mathrm{mg}$, potassium - $4700 \mathrm{mg}$, sodium - $1500 \mathrm{mg}$, magnesium - $410 \mathrm{~g}$, zinc $11.000 \mu \mathrm{g}$, iron - $10.000 \mu \mathrm{m}$, copper - $900 \mu \mathrm{g}$ (Jarosz and Charzewska 2012; Jarosz and Traczyk 2012; Jarosz et al. 2012a, b; Szponar et al. 2012; Wojtasik et al. 2012). 
The results were processed statistically by one-way ANOVA in the Statistica 12 program (StatSoft, Kraków, Poland) and were presented as mean values with standard deviation. The significance of differences between means was determined by Tukey's HSD test at $p=0.05$.

\section{RESULTS AND DISCUSSION}

The proximate chemical composition of the analyzed ricotta is presented in Table 2. The average dry matter content ranged from $19.17 \%$ (manufacturer $D$ ) to $30.78 \%$ (manufacturer $A$ ). The evaluated ricotta samples differed significantly $(p<0.05)$ in their dry matter content. The average total protein content was determined in the range of $7.52 \%$ (manufacturer $C$ ) to $8.97 \%$ (manufacturer $\mathrm{D}$ ). The products supplied by manufacturers $A$ and $\mathrm{D}$ did not differ significantly $(p>0.05)$ in their total protein content, but they were significantly $(p<0.05)$ more abundant in protein than the products supplied by manufacturers $B$ and $C$.

Table 2. Chemical composition of the analyzed ricotta Tabela 2. Skład chemiczny badanych ricott

\begin{tabular}{|c|c|c|c|c|c|}
\hline Ricotta & $\begin{array}{c}\text { Dry matter } \\
\text { Sucha masa } \\
{[\%]}\end{array}$ & $\begin{array}{c}\text { Total protein } \\
\text { Białko ogółem } \\
\text { [\%] }\end{array}$ & $\begin{array}{c}\text { Fat } \\
\text { Tłuszcz } \\
{[\%]}\end{array}$ & $\begin{array}{c}\text { Lactose } \\
\text { Laktoza } \\
\text { [\%] }\end{array}$ & $\begin{array}{c}\text { Ash } \\
\text { Popió } \\
\text { [\%] }\end{array}$ \\
\hline $\begin{array}{l}\text { Manufacturer } \\
\text { Producent } \\
\text { A }\end{array}$ & $\begin{array}{l}30.78 a \\
\pm 0.03\end{array}$ & $\begin{array}{r}8.86 a \\
\pm 0.08\end{array}$ & $\begin{array}{l}13.25 a \\
\pm 0.29\end{array}$ & $\begin{array}{r}5.70 a \\
\pm 0.01\end{array}$ & $\begin{array}{r}1.39 \mathrm{~b} \\
\pm 0.01\end{array}$ \\
\hline $\begin{array}{l}\text { Manufacturer } \\
\text { Producent } \\
\text { B }\end{array}$ & $\begin{array}{l}20.00 \mathrm{c} \\
\pm 0.06\end{array}$ & $\begin{array}{l}7.96 \mathrm{~b} \\
\pm 0.09\end{array}$ & $\begin{array}{l}7.13 c \\
\pm 0.25\end{array}$ & $\begin{array}{l}3.26 c \\
\pm 0.02\end{array}$ & $\begin{array}{r}1.34 c \\
\pm 0.01\end{array}$ \\
\hline $\begin{array}{l}\text { Manufacturer } \\
\text { Producent } \\
\text { C }\end{array}$ & $\begin{array}{l}27.08 b \\
\pm 0.06\end{array}$ & $\begin{array}{l}7.52 c \\
\pm 0.05\end{array}$ & $\begin{array}{l}11.38 \mathrm{~b} \\
\pm 0.25\end{array}$ & $\begin{array}{l}4.76 b \\
\pm 0.03\end{array}$ & $\begin{array}{r}1.88 a \\
\pm 0.02\end{array}$ \\
\hline $\begin{array}{l}\text { Manufacturer } \\
\text { Producent } \\
\text { D }\end{array}$ & $\begin{array}{l}19.17 d \\
\pm 0.06\end{array}$ & $\begin{array}{l}8.97 a \\
\pm 0.09\end{array}$ & $\begin{array}{l}6.50 d \\
\pm 0.00\end{array}$ & $\begin{array}{l}2.52 d \\
\pm 0.02\end{array}$ & $\begin{array}{l}0.50 d \\
\pm 0.01\end{array}$ \\
\hline
\end{tabular}

Mean value \pm standard deviation - Wartość średnia \pm odchylenie standardowe $(n=4)$.

Mean values denoted by different letters in the same column differ significantly - Wartości średnie oznaczone $w$ tej samej kolumnie inną literą różnią się statystycznie istotnie $(p<0,05)$.

According to label data, all of the analyzed products were made from whey (Table 1) and contained whey protein. Whey protein has higher biological value than whole egg protein, it is a rich source of essential amino acids, and has numerous health benefits, including anticarcinogenic and immunomodulatory properties (Smithers 2008). The evaluated ricotta products differed in their fat content which ranged from $6.50 \%$ (manufacturer $D$ ) to $13.25 \%$ (manufacturer A) on average, and the observed differences in the fat content of products supplied by various manufacturers were statistically significant $(p<0.05)$. The fat content of ricotta increased with a rise in dry matter content. According to Jasińska and Skryplonek (2015), fat levels in ricotta are linked with water content and increase with a decrease in water content. Lactose is responsible for the slightly sweet flavor of ricotta (Kolanowski 2005). The highest average lactose content was determined in ricotta supplied by manufacturer $\mathrm{A}$ at $5.70 \%$, whereas the product from manufacturer $D$ was least abundant in lactose at $2.52 \%$ on average. The examined products differed significantly $(p<0.05)$ in their lactose content. The average content of mineral constituents expressed as ash ranged from $0.50 \%$ (manufacturer $D$ ) 
to $1.88 \%$ (manufacturer $\mathrm{C}$ ). The differences in the ash content of ricotta supplied by various manufacturers were statistically significant $(p<0.05)$. The lowest lactose and ash content of ricotta supplied by manufacturer $D$ could indicate that this product was made from ultrafiltered whey (Jayaprakasha and Yoon 2005).

Other authors have also reported considerable variations in the chemical composition of ricotta. In a study by Jasińska and Skryplonek (2015), ricotta supplied by four manufacturers and sold on the Polish market contained $67.82-82.77 \%$ water and $2.2-16.5 \%$ fat on the day of purchase. Esper et al. (2007) analyzed 15 ricotta brands available on the Brazilian market and determined their water content at $62.22-77.08 \%$, total protein content at $8.78-13.73 \%$, fat content at $5.89-24.22 \%$, and ash content at $0.46-3.84 \%$ on average.

The mineral composition of the evaluated ricotta is presented in Table 3 . The average calcium content ranged from $26.17 \mathrm{mg} \cdot 100 \mathrm{~g}^{-1}$ (manufacturer D) to $218.65 \mathrm{mg} \cdot 100 \mathrm{~g}^{-1}$ (manufacturer $C$ ). Ricotta supplied by manufacturer $C$ was significantly $(p<0.05)$ more abundant in calcium, whereas the product supplied by manufacturer $D$ contained significantly $(p<0.05)$ less calcium than products supplied by manufacturers $A$ and $B$. The average phosphorus content of the examined ricotta was determined in the range of $22.24 \mathrm{mg} \cdot 100 \mathrm{~g}^{-1}$ (manufacturer D) to $117.48 \mathrm{mg} \cdot 100 \mathrm{~g}^{-1}$ (manufacturer $C$ ). Significant differences $(p<0.05)$ were noted in the phosphorus content of the evaluated products. Ricotta from manufacturer $D$ contained approximately 5.1 - to 8.4 - fold less calcium and around 3.5 - to 5.3 - fold less phosphorus than the products supplied by manufacturers A, B and C. In a study by Wong et al. (1978), the average calcium content of ricotta was determined at $365.5 \mathrm{mg} \cdot 100 \mathrm{~g}^{-1}$, and the average phosphorus content - at $219.5 \mathrm{mg} \cdot 100 \mathrm{~g}^{-1}$. The availability of calcium is largely influenced by the $\mathrm{Ca}: \mathrm{P}$ ratio, and the optimal $\mathrm{Ca}: \mathrm{P}$ ratio in the daily diet should not be lower than $1.3: 1$ (Śmigielska et al. 2005; Kusiuk et al. 2009). In this study, a highly favorable Ca : P ratio was noted in ricotta from manufacturers $A(C a: P=1.59: 1), B(C a: P=1.73: 1)$ and $C$ $(\mathrm{Ca}: \mathrm{P}=1.86: 1)$, whereas in product $\mathrm{D}$, the $\mathrm{Ca}: \mathrm{P}$ ratio was somewhat below the optimal range $(\mathrm{Ca}: \mathrm{P}=1.18: 1)$.

Table 3. The content of macroelements and microelements in the analyzed ricotta Tabela 3. Zawartość makroelementów i mikroelementów w badanych ricottach

\begin{tabular}{|c|c|c|c|c|c|c|c|c|}
\hline \multirow[t]{2}{*}{ Ricotta } & \multicolumn{5}{|c|}{$\begin{array}{l}\text { Macroelements } \\
\text { Makroelementy } \\
{\left[\mathrm{mg} \cdot 100 \mathrm{~g}^{-1}\right]}\end{array}$} & \multicolumn{3}{|c|}{$\begin{array}{l}\text { Microelements } \\
\text { Mikroelementy } \\
{\left[\mu \mathrm{g} \cdot 100 \mathrm{~g}^{-1}\right]}\end{array}$} \\
\hline & $\mathrm{Ca}$ & $\mathrm{P}$ & $\mathrm{K}$ & $\mathrm{Na}$ & $\mathrm{Mg}$ & $\mathrm{Zn}$ & $\mathrm{Fe}$ & $\mathrm{Cu}$ \\
\hline $\begin{array}{l}\text { Manufacturer } \\
\text { Producent } \\
\text { A }\end{array}$ & $\begin{array}{c}140.91 b \\
\pm 1.41\end{array}$ & $\begin{array}{c}88.42 b \\
\pm 2.04\end{array}$ & $\begin{array}{c}107.66 a \\
\pm 1.10\end{array}$ & $\begin{array}{l}29.55 d \\
\pm 0.64\end{array}$ & $\begin{array}{r}8.48 c \\
\pm 0.15\end{array}$ & $\begin{array}{l}87.84 b \\
\pm 1.85\end{array}$ & $\begin{array}{c}58.34 a \\
\pm 1.67\end{array}$ & $\begin{array}{c}16.44 \mathrm{~b} \\
\pm 0.75\end{array}$ \\
\hline $\begin{array}{l}\text { Manufacturer } \\
\text { Producent } \\
\text { B }\end{array}$ & $\begin{array}{c}134.33 b \\
\pm 5.66\end{array}$ & $\begin{array}{l}77.86 c \\
\pm 2.10\end{array}$ & $\begin{array}{l}58.96 c \\
\pm 2.42\end{array}$ & $\begin{array}{l}59.91 b \\
\pm 0.98\end{array}$ & $\begin{array}{l}12.24 a \\
\pm 0.95\end{array}$ & $\begin{array}{l}66.12 c \\
\pm 3.76\end{array}$ & $\begin{array}{l}46.38 c \\
\pm 2.51\end{array}$ & $\begin{array}{l}16.38 \mathrm{~b} \\
\pm 0.94\end{array}$ \\
\hline $\begin{array}{l}\text { Manufacturer } \\
\text { Producent } \\
\text { C }\end{array}$ & $\begin{array}{c}218.65 a \\
\pm 6.20\end{array}$ & $\begin{array}{c}117.48 \mathrm{a} \\
\pm 1.55\end{array}$ & $\begin{array}{l}83.81 b \\
\pm 4.27\end{array}$ & $\begin{array}{c}95.74 a \\
\pm 1.03\end{array}$ & $\begin{array}{l}10.55 b \\
\pm 0.35\end{array}$ & $\begin{array}{c}153.48 a \\
\pm 2.76\end{array}$ & $\begin{array}{l}50.20 \mathrm{~b} \\
\pm 1.17\end{array}$ & $\begin{array}{l}17.90 \mathrm{a} \\
\pm 0.51\end{array}$ \\
\hline $\begin{array}{l}\text { Manufacturer } \\
\text { Producent } \\
\text { D }\end{array}$ & $\begin{array}{l}26.17 c \\
\pm 0.36\end{array}$ & $\begin{array}{l}22.24 d \\
\pm 0.10\end{array}$ & $\begin{array}{l}46.63 d \\
\pm 1.88\end{array}$ & $\begin{array}{l}45.50 c \\
\pm 0.73\end{array}$ & $\begin{array}{l}2.63 d \\
\pm 0.09\end{array}$ & $\begin{array}{l}36.88 d \\
\pm 2.65\end{array}$ & $\begin{array}{l}37.24 d \\
\pm 2.00\end{array}$ & $\begin{array}{l}15.70 \mathrm{~b} \\
\pm 0.66\end{array}$ \\
\hline
\end{tabular}

Mean value \pm standard deviation - Wartość średnia \pm odchylenie standardowe $(n=5)$.

Mean values denoted by different letters in the same column differ significantly - Wartości średnie oznaczone $w$ tej samej kolumnie inną literą różnią się statystycznie istotnie $(p<0,05)$. 
The average potassium content of the evaluated ricotta ranged from $46.63 \mathrm{mg} \cdot 100 \mathrm{~g}^{-1}$ (manufacturer D) to $107.66 \mathrm{mg} \cdot 100 \mathrm{~g}^{-1}$ (manufacturer A), and the average sodium content from $29.55 \mathrm{mg} \cdot 100 \mathrm{~g}^{-1}$ (manufacturer $\mathrm{A}$ ) to $95.74 \mathrm{mg} \cdot 100 \mathrm{~g}^{-1}$ (manufacturer C). Significant differences $(p<0.05)$ in potassium and sodium content were observed between ricotta products supplied by various manufacturers. The ricotta analyzed by Wong et al. (1978) was characterized by average potassium content of $156.7 \mathrm{mg} \cdot 100 \mathrm{~g}^{-1}$ and average sodium content of $224.9 \mathrm{mg} \cdot 100 \mathrm{~g}^{-1}$. The sodium content of ricotta is determined by the amount of added salt. According to label data, sodium chloride was used in the production of ricotta supplied by manufacturers $B, C$ and $D$, but not in ricotta supplied by manufacturer $A$ (Table 1), which could explain the lowest sodium content of the product from manufacturer A. In a study by Jasińska and Skryplonek (2015), ricotta purchased on the Polish market contained $0.137-0.278 \%$ sodium chloride on average. The $\mathrm{K}$ : Na ratio is a very important consideration in a balanced diet, and it should not be lower than $3.13: 1$ in diets recommended for men and women aged 19-50 years (Jarosz et al. 2012a). The optimal K : Na ratio was noted in ricotta supplied by manufacturer $\mathrm{A}(\mathrm{K}: \mathrm{Na}=3.64: 1)$, whereas the remaining products were significantly deficient in potassium relative to sodium $(\mathrm{K}: \mathrm{Na}=0.88-1.03: 1)$.

The magnesium content of the analyzed ricotta ranged from $2.63 \mathrm{mg} \cdot 100 \mathrm{~g}^{-1}$ (manufacturer D) to $12.24 \mathrm{mg} \cdot 100 \mathrm{~g}^{-1}$ (manufacturer B) on average. Significant differences in magnesium content were observed between products supplied by various manufacturers. In a study by Wong et al. (1978), the average magnesium content of ricotta was determined at $20.4 \mathrm{mg} \cdot 100 \mathrm{~g}^{-1}$.

The analyzed ricotta contained $36.88 \mu \mathrm{g} \cdot 100 \mathrm{~g}^{-1}$ (manufacturer D) to $153.48 \mu \mathrm{g} \cdot 100 \mathrm{~g}^{-1}$ (manufacturer C) of zinc, and 37.24 (manufacturer D) to $58.34 \mu \mathrm{g} \cdot 100 \mathrm{~g}^{-1}$ (manufacturer A) of iron on average. The observed differences in the zinc and iron content of ricotta were statistically significant $(p<0.05)$. In the work of Wong et al. (1978), ricotta contained $1335.0 \mu \mathrm{g} \cdot 100 \mathrm{~g}^{-1}$ of zinc $443.2 \mu \mathrm{g} \cdot 100 \mathrm{~g}^{-1}$ of iron on average.

Table 4. Energy value of the analyzed ricotta Tabela 4. Wartość energetyczna badanych ricott

\begin{tabular}{|c|c|c|c|c|}
\hline \multirow{2}{*}{ Ricotta } & \multirow{2}{*}{$\begin{array}{c}\text { Energy value } \\
\text { Wartość energetyczna } \\
{\left[\mathrm{kcal} \cdot 100 \mathrm{~g}^{-1}\right]}\end{array}$} & \multicolumn{3}{|c|}{$\begin{array}{c}\text { Percentage of dietary energy } \\
\text { Udział składników w wartości energetycznej }\end{array}$} \\
\hline & & $\begin{array}{c}\text { protein } \\
\text { białko } \\
{[\%]}\end{array}$ & $\begin{array}{c}\text { fat } \\
\text { tłuszcz } \\
{[\%]}\end{array}$ & $\begin{array}{c}\text { sugars } \\
\text { cukry } \\
{[\%]}\end{array}$ \\
\hline $\begin{array}{l}\text { Manufacturer } \\
\text { Producent } \\
\text { A }\end{array}$ & 177.49 & 19.97 & 67.19 & 12.85 \\
\hline $\begin{array}{l}\text { Manufacturer } \\
\text { Producent } \\
\text { B } \\
\text { Manufacturer }\end{array}$ & 109.05 & 29.20 & 58.84 & 11.96 \\
\hline $\begin{array}{l}\text { Producent } \\
\text { C } \\
\text { Manufacturer }\end{array}$ & 151.54 & 19.85 & 67.59 & 12.56 \\
\hline $\begin{array}{l}\text { Producent } \\
\text { D }\end{array}$ & 104.46 & 34.35 & 56.00 & 9.65 \\
\hline
\end{tabular}


Table 5. The INQ values for ricotta based on the recommended dietary allowances (protein, fat, available sugars, $\mathrm{Ca}, \mathrm{P}, \mathrm{Mg}, \mathrm{Zn}, \mathrm{Fe}, \mathrm{Cu}$ ) or adequate intake $(\mathrm{K}, \mathrm{Na})$ of nutrients, calculated separately for moderately physically active men and women aged 19-50.

Tabela. 5. Wartości INQ badanych ricott, obliczone dla składników odżywczych w odniesieniu do uśrednionego spożycia (w przypadku białka, tłuszczu, cukrów, $\mathrm{Ca}, \mathrm{P}, \mathrm{Mg}, \mathrm{Zn}, \mathrm{Fe}, \mathrm{Cu}$ ) lub wystarczającego spożycia (w przypadku K, Na), oddzielnie dla populacji kobiet i mężczyzn w wieku 19-50 lat, o umiarkowanej aktywności fizycznej

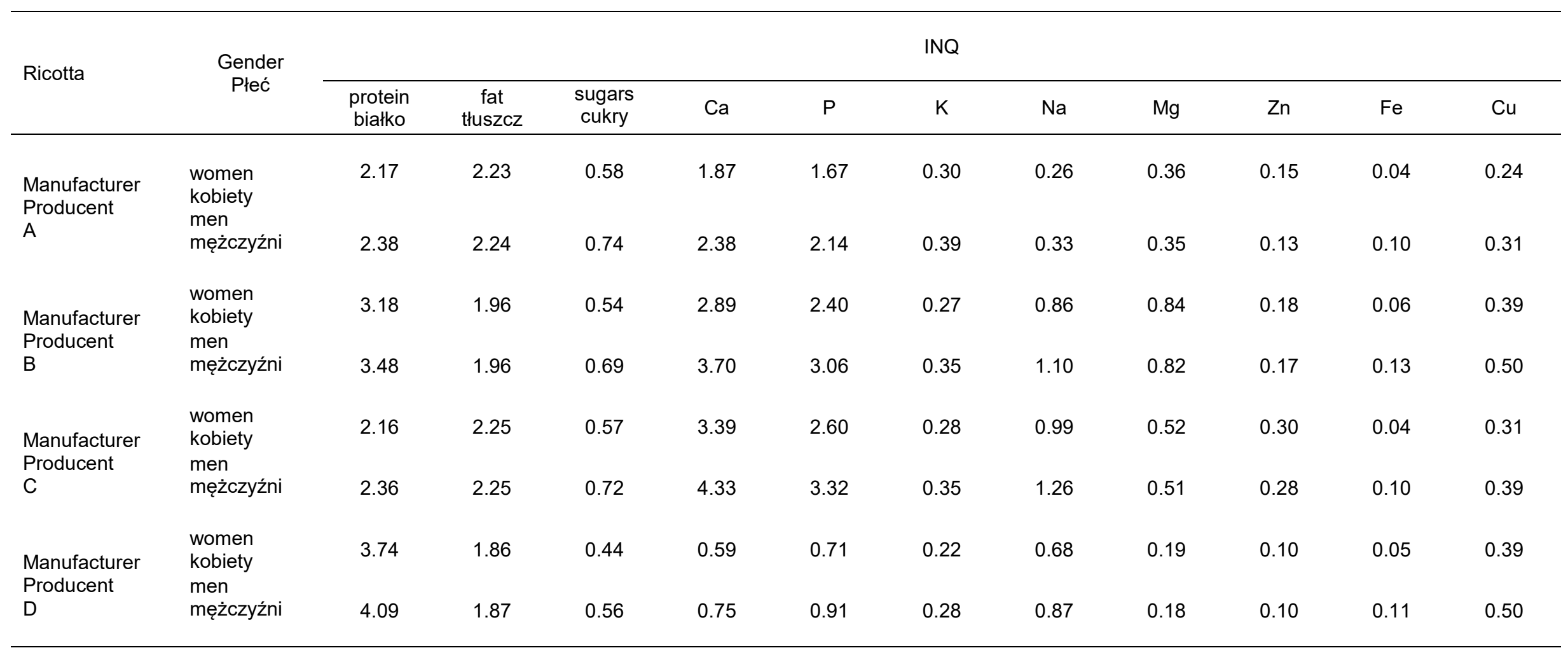


The average copper content of the examined ricotta ranged from $15.70 \mu \mathrm{g} \cdot 100 \mathrm{~g}^{-1}$ (manufacturer D) to $17.90 \mu \mathrm{g} \cdot 100 \mathrm{~g}^{-1}$ (manufacturer $\mathrm{C}$ ). Ricotta supplied by manufacturer $\mathrm{C}$ was significantly $(p<0.05)$ more abundant in copper than ricotta supplied by manufacturers $A, B$ and $D$ where the differences in copper content were not statistically significant $(p>0.05)$. The average copper content of ricotta evaluated by Wong et al. (1978) was $34.0 \mu \mathrm{g} \cdot 100 \mathrm{~g}^{-1}$.

The energy value of the analyzed ricotta is presented in Table 4. The lowest energy value of $104.46 \mathrm{kcal} \cdot 100 \mathrm{~g}^{-1}$ was noted in ricotta from manufacturer $\mathrm{D}$, whereas the highest energy value of $177.49 \mathrm{kcal} \cdot 100 \mathrm{~g}^{-1}$ was found in ricotta from manufacturer A. Ricotta from manufacturers $A$ and $C$ had higher fat content and, consequently, higher energy value $\left(177.49 \mathrm{kcal} \cdot 100 \mathrm{~g}^{-1}\right.$ and $151.54 \mathrm{kcal} \cdot 100 \mathrm{~g}^{-1}$, respectively) than ricotta from manufacturers $B$ and $D\left(109.05 \mathrm{kcal} \cdot 100 \mathrm{~g}^{-1}\right.$ and $104.46 \mathrm{kcal} \cdot 100 \mathrm{~g}^{-1}$, respectively). The percentage of energy supplied by the analyzed nutrients was very similar in the products from manufacturers $A$ and $C$, and it was estimated at approximately $20 \%$ for protein, $67-68 \%$ for fat and $13 \%$ for sugars. In ricotta from manufacturers B and D, protein supplied approximately $29 \%$ and $34 \%$ of dietary energy, fat $59 \%$ and $56 \%$, and sugars $-12 \%$ and $10 \%$, respectively. In a study by Camini et al. (2014), the energy value of ricotta purchased on the Brazilian market ranged from $104.78 \mathrm{kcal} \cdot 100 \mathrm{~g}^{-1}$ to $276.03 \mathrm{kcal} \cdot 100 \mathrm{~g}^{-1}$, and the observed differences were determined mainly by fat content.

The Index of Nutritional Quality (INQ) is the ratio between the percentage of the reference intake of a given nutrient and the percentage of the average requirement for energy provided by a food product. The INQ is calculated to determine whether various foods meet the specific nutritional and energy needs of a population. An INQ lower than 1 is indicative of a nutrient deficiency, an INQ of 1 points to a well-balanced diet, whereas an INQ higher than 1 indicates that a given food product is a rich source of a given nutrient and is recommended for individuals who are deficient in that element (Gawęcki and Roszkowski 2010). The INQ values of ricotta relative to the average nutritional requirements of moderately physically active men and women aged 19-50 years are presented in Table 5. The calculated values of the INQ indicate that all analyzed ricotta samples were abundant in protein (INQ $=2.16-4.09)$ and fat $(\mathrm{INQ}=1.86-2.25)$. High levels of calcium (INQ = 1.87-4.33) and phosphorus (INQ = 1.67-3.32) were found in ricotta from manufacturers $A, B$ and $C$, but not in ricotta from manufacturer $D$ $(\mathrm{INQ}<1)$. The INQ values for sodium approximated 1 in ricotta from manufacturers $B$ and $C$ (INQ = 0.86-1.26), but were below 1 in ricotta from manufacturers $A$ and $D(I N Q=0.26-0.87)$. In all analyzed ricotta samples, INQ values were determined below 1 for sugars (INQ $=0.44-0.74$ ), potassium (INQ $=0.22-0.39$ ), magnesium (INQ $=0.18-0.84$ ), zinc (INQ $=0.10-0.30$ ), iron $(\mathrm{INQ}=0.04-0.13)$ and copper $(\mathrm{INQ}=0.24-0.50)$, which suggests that none of the evaluated products met the above nutrient requirements for moderately physically active men and women aged $19-50$ years.

\section{CONCLUSIONS}

Ricotta purchased on the Polish retail market and analyzed in this study was characterized by differences in chemical composition. The observed variations in the energy value of ricotta were determined by the content of fat, the main source of energy in the evaluated dairy products. 
The calculated INQ values indicate that the analyzed ricotta was a rich source of protein and fat $(\mathrm{INQ}>1)$. Three of the four examined products were abundant in calcium and phosphorus $(\mathrm{INQ}>1)$, and their $\mathrm{Ca}: \mathrm{P}$ ratio improved the bioavailability of calcium (Ca : $\mathrm{P}>1.3: 1)$. The optimal $\mathrm{K}: \mathrm{Na}$ ratio $(\mathrm{K}: \mathrm{Na}>3.13)$ was noted in ricotta supplied by one manufacturer.

Products from two manufacturers were a rich source of sodium $(I N Q \approx 1)$. The analyzed ricotta, supplied by four different manufacturers, did not adequately meet the nutritional requirements of moderately physically active men and women aged 19-50 (INQ < 1) for sugars, potassium, magnesium, zinc, iron and copper.

\section{REFERENCES}

Biernat J., Wyka J. 2011. Stan odżywienia w aspekcie stanu zdrowia [Nutrition status and health status]. Now. Lek. 80(3), 209-212. [in Polish]

Camini A., Müller C., Bildhauer D.C., Souza C.F.V. 2014. Características físico-químicas de ricotas comercializadas no vale do Taquari [Physicochemical properties of ricotta sold in the Taquari valley]. Rev. Dest. Acad. 6(4), 96-100. [in Portuguese]

Esper L.M.R., Bonets P.A., Kuaye A.Y. 2007. Avaliação das características físico-químicas de ricotas comercializadas no município de Campinas-SP e da conformidade das informações nutricionais declaradas nos rótulos [Physical-chemical characteristics of the ricotta cheese samples on sale in the local markets of Campinas City, SP, Brazil, and the compliance of the nutritional information on the labels assessment]. Rev. Inst. Adolfo Lutz 66(3), 299-304. [in Portuguese]

Gawęcki J., Roszkowski W. 2010. Wskaźniki charakteryzujące wartość odżywczą żywności, w: Żywienie człowieka. Podstawy nauki o żywieniu. Tom 1. Red. J. Gawęcki. Warszawa, PWN, 368-386. [in Polish]

Jarosz M., Charzewska J. 2012. Białka, w: Normy żywienia dla populacji polskiej - nowelizacja. Red. M. Jarosz. Warszawa, Wydaw. İ̇ż, 32-43. [in Polish]

Jarosz M., Traczyk I. 2012. Węglowodany, w: Normy żywienia dla populacji polskiej - nowelizacja. Red. M. Jarosz. Warszawa, Wydaw. IŻŻ, 63-74. [in Polish]

Jarosz M., Szponar L., Rychlik E., Wierzejska R. 2012a. Woda i elektrolity, w: Normy żywienia dla populacji polskiej - nowelizacja. Red. M. Jarosz. Warszawa, Wydaw. İ̇ż, 143-153. [in Polish]

Jarosz M., Traczyk I., Rychlik E. 2012b. Energia, w: Normy żywienia dla populacji polskiej nowelizacja. Red. M. Jarosz. Warszawa, Wydaw. IŻŻ, 18-31. [in Polish]

Jasińska M., Skryplonek K. 2015. Charakterystyka wybranych cech jakościowych serów ricotta w czasie chłodniczego przechowywania [Characterisctic of selected quality features of ricotta cheeses during refrigerated storage]. TPJ 2(43), 80-91. [in Polish]

Jayaprakasha H.M., Yoon Y.C. 2005. Production of functional whey protein concentrate by monitoring the process of ultrafilteration. Asian Austral. J. Anim. Sci. 18(3), 433-438.

Kolanowski W. 2005. Serwujemy sery [Serving cheese]. Prz. Gastronom. 4, 10. [in Polish].

Krełowska-Kułas M. 1993. Badanie jakości produktów spożywczych. Warszawa, PWE. [in Polish]

Kusiuk A., Grembecka M., Szefer P. 2009. Wzajemne relacje stężeń Ca i P w serach źródłem prawidłowo zbilansowanej diety [Interrelations between calcium and phosphorus content in different kind of cheeses as a source of well-balanced diet]. Bromat. Chem. Toksykol. 42(3), 798-802. [in Polish]

Markiewicz K. 2000. Oznaczanie zawartości wapnia i fosforu w produktach spożywczych, w: Ćwiczenia z analizy żywności. Red. Z. Żegarska. Olsztyn, Wydaw. UWM, 67-72. [in Polish]

Mucchetti G., Carminati D., Pirisi A. 2002. Ricotta fresca vaccina ed ovina: osservazioni sulle tecniche di produzione e sul prodotto [Fresh ricotta from cow's and ewe's milk: production technology and products]. Latte 27(2), 154-166. [in Italian] 
Pintado M.E., Macedo A.C., Malcata F.X. 2001. Review: technology, chemistry and microbiology of whey cheeses. Food Sci. Tech. Int. 7(2), 105-116.

PN-A-86232. 1973. Mleko i przetwory mleczarskie. Sery. Metody badań. [in Polish]

PN-EN ISO 8968-2. 2004. Mleko. Oznaczanie zawartości azotu. Część 2. Metoda z zastosowaniem bloku do mineralizacji (metoda makro). [in Polish]

PN-EN ISO 5534. 2005. Sery i sery topione. Oznaczanie zawartości całkowitej suchej masy (metoda odwoławcza). [in Polish]

Smithers G.W. 2008. Whey and whey proteins. From 'gutter-to-gold'. Int. Dairy J. 18, 695-704.

Szponar L., Mojska H., Ołtarzewski M. 2012. Tłuszcze, w: Normy żywienia dla populacji polskiej nowelizacja. Red. Ed. M. Jarosz. Warszawa, Wydaw. IŻŻ, 44-58. [in Polish]

Śmigielska H., Lewandowicz G., Gawęcki J. 2005. Biopierwiastki w żywności. Przyswajalność składników mineralnych [Bioavailability of minerals. Bioelements in food]. Przem. Spoż. 7, 28-32. [in Polish]

Whiteside P.J., Miner B. 1984. Pye unicam atomic absorption data book. Cambridge UK, Pye Unicam Ltd.

Wojtasik A., Jarosz M. Stoś K. 2012. Składniki mineralne, w: Normy żywienia dla populacji polskiej nowelizacja. Red. M. Jarosz. Warszawa, Wydaw. İ̇Ż, 123-142. [in Polish]

Wong N.P., LaCroix D.E., Alford J.A. 1978. Mineral content of dairy products. II. Cheeses. J. Am. Diet. Assoc. 72(6), 608-611.

\begin{abstract}
The nutritional value of ricotta sold on the Polish market was evaluated. The experiment was performed on fresh (unripened) ricotta supplied by four manufacturers, purchased in retail in the city of Olsztyn, Poland. Ricotta samples were analyzed to determine their dry matter content - by the drying method, total protein content - by the block-digestion (macro) method, fat content - by the butyrometric method, lactose content - by the Bertrand method, and ash content by incineration. The mineral content of ricotta samples was determined by wet mineralization. The content of $\mathrm{Ca}, \mathrm{Mg}, \mathrm{Zn}, \mathrm{Fe}$ and $\mathrm{Cu}$ was analyzed by flame atomic absorption spectroscopy (air-acetylene flame), the content of $\mathrm{K}$ and $\mathrm{Na}$ - by atomic emission spectroscopy (air-acetylene flame), and the content of $P$ was determined in a colorimetric assay. The energy value of the analyzed products was estimated. The nutritional value of ricotta was determined by calculating the Index of Nutritional Quality (INQ) based on the reference values for moderately physically active women and men aged $19-50$ years. The evaluated ricotta samples were characterized by differences in chemical composition. Their energy value was determined mainly by fat content. The values of INQ indicate that the analyzed ricotta was a rich source of protein and fat. Ricotta from three manufacturers had high $\mathrm{Ca}$ and $\mathrm{P}$ content, and the $\mathrm{Ca}$ : $\mathrm{P}$ ratio increased the bioavailability of $\mathrm{Ca}$. Ricotta from two manufacturers was abundant in $\mathrm{Na}$, and ricotta from one manufacturer was characterized by an optimal $\mathrm{K}$ : Na ratio. The evaluated products were a poor source of sugars, $\mathrm{K}, \mathrm{Mg}, \mathrm{Zn}, \mathrm{Fe}$ and $\mathrm{Cu}$ for moderately physically active men and women aged 19-50 years.
\end{abstract}

This study is part of statutory research project No. 17.610.002-300, entitled: „Food quality and safety during processing, packaging and storage", carried out by the University of Warmia and Mazury. 